\title{
PERTUMBUHAN DAN SINTASAN UDANG VANAME (Litopenaeus vannameI) DENGAN KOMBINASI PAKAN BERBEDA DALAM WADAH TERKONTROL
}

\author{
Suwardi Tahe dan Hidayat Suryanto Suwoyo \\ Balai Riset Perikanan Budidaya Air Payau \\ Jl. Makmur Daeng Sitakka No. 129, Maros 90512, Sulawesi Selatan \\ E-mail: litkanta@indosat.net.id
}

(Naskah diterima: 15 Juni 2010; Disetujui publikasi: 26 Maret 2011)

\begin{abstract}
ABSTRAK
Pakan merupakan satu di antara faktor yang perlu diperhatikan dalam sistem budidaya udang di tambak, karena berpengaruh terhadap pertumbuhan, sintasan, dan efisiensi biaya produksi. Penelitian ini bertujuan untuk mengetahui kombinasi pakan yang tepat terhadap pertumbuhan dan sintasan udang vaname (Litopenaeus vannamei). Penelitian dilaksanakan di Instalasi Perbenihan Balai Riset Perikanan Budidaya Air Payau. Wadah yang digunakan adalah bak fiber glass ukuran $1 \mathrm{~m} \times 1 \mathrm{~m} \times 0,7 \mathrm{~m}$ sebanyak 9 buah. Setiap bak diisi air laut salinitas 32 ppt sebanyak $500 \mathrm{~L}$ dan dilengkapi 1 buah aerasi. Hewan uji yang digunakan adalah tokolan udang vaname dengan bobot rata-rata 0,45 g/ekor dan ditebar kepadatan 100 ekor/bak. Penelitian diset menggunakan Rancangan Acak Lengkap dengan 3 perlakuan yaitu: (A) pakan PV 100\%, (B) pakan PV 75\% + pakan EB 25\%, dan (C) pakan PV 50\% + EB 50\%, masing-masing perlakuan diulang tiga kali. Selama pemeliharan 85 hari, udang diberi pakan dosis $50-5 \%$ dari total bobot biomassa/hari. Hasil penelitian yang diperoleh menunjukkan bahwa kombinasi pakan berpengaruh nyata $(P<0,05)$ terhadap pertumbuhan, sintasan, rasio konversi pakan, dan produksi udang vaname. Pertumbuhan dan sintasan udang vaname terbaik yaitu masing-masing $6,31 \mathrm{~g}$ dan $86 \%$ diperoleh pada perlakuan B bila dibanding perlakuan lainnya.
\end{abstract}

KATA KUNCI: pertumbuhan, sintasan, pakan, udang vaname

ABSTRACT: Growth and survival rate of pacific white shrimp (L. vannamei) treated with different feed combinations in controlled media. By: Suwardi Tahe and Hidayat Suryanto Suwoyo

One of the main important factors in shrimp culture is the availability of feed because it has a profound effect on the growth and survival rate of cultured fish and the cost production of the aquaculture itself. The main purpose of this research was to study the impact of different feeds on the growth and survival rate of pacific white shrimp (L. vannamei). The experiment was conducted in a hatchery owned by the Research Institute for Coastal Aquaculture (RICA), South Sulawesi. Nine unit fiber glass tanks 1 $\times 1 \times 0.7 \mathrm{~m}$ in size were used as the media. Each tank were filled with $500 \mathrm{~L}$ of $32 \mathrm{ppt}$ salinity sea water and equipped with 1 aeration system/tank and stocked with 100 ind/tank of $0.45 \mathrm{~g} /$ ind initial average weight of vannamei juvenile. The research employed Completely Randomized Design with three treatments and three replications. The treatments were: (A) feed PV $100 \%$, (B) feed combination PV $75 \%+E B$ $25 \%$, and (C) feed combination with PV 50\% + EB 50\%. During the experiment, the fish were fed with 50-5\% biomass/day dosage of the commercial diets. The result showed that feed combination treatments had significantly different $(P<0.05)$ effect on the 
growth rate, survival rate, feed convertion ratio, and cost production of pacific white shrimp (L. vannamei).

KEYWORDS: growth, survival rate, feed, L. vannamei

\section{PENDAHULUAN}

Udang vaname (Litopenaeus vannamei) biasa juga disebut Penaeus vannamei, Pasific white shrimp, West coast white shrimp dan Camaron blanco langostino, sedangkan nama FAO-nya adalah White leg shrimp, Crevette pettes blanches, Camoron pattiblanco (Holthius et al., 1980). Keunggulan udang ini antara lain: ukuran PL 6-7 sudah merupakan benur yang siap tebar selain kepadatan tebarnya tinggi, tahan terhadap goncangan lingkungan dan juga memiliki sintasan yang tinggi (Poernomo, 2002; Anonim, 2003).

Usaha peningkatan produksi udang vaname dapat dilakukan melalui usaha budidaya secara intensif dengan penerapan sapta usaha pertambakan secara utuh dan menyeluruh. Salah satu di antaranya adalah pemberian pakan yang efektif dan efisien. Penyediaan pakan berkualitas tinggi merupakan faktor penting yang menentukan keberhasilan budidaya udang. Pada kegiatan budidaya udang vaname, ketersediaan pakan yang tepat, baik secara kualitas maupun kuantitas merupakan syarat mutlak untuk mendukung pertumbuhannya, yang pada akhirnya dapat meningkatkan produksi. Pemberian pakan dalam jumlah yang berlebihan dapat meningkatkan biaya produksi dan pemborosan serta menyebabkan sisa pakan yang berlebihan akan berakibat pada penurunan kualitas air sehingga berpengaruh pada pertumbuhan dan sintasan udang (Wyban \& Sweeny, 1991).

Pada usaha budidaya intensif, pakan merupakan faktor yang sangat penting dalam budidaya udang, karena menyerap 60\%-70\% dari total biaya produksi udang (Palinggi \& Atmomarsono, 1988; Padda \& Mangampa, 1993). Komposisi kandungan protein, karbohidrat, lemak, dan lain-lainnya harus disesuaikan dengan kebutuhan udang, sehingga dapat mencapai pertumbuhan dan sintasan yang optimum. Perlu diupayakan untuk selalu menekan biaya pakan melalui penggunaan pakan secara efisien agar udang dapat tumbuh optimum dan pakan yang terbuang seminimum mungkin. Salah satu upaya yang dilakukan untuk mengontrol pemberian pakan yang berlebihan adalah dengan cara pengelolaan pakan yakni dengan pengaturan pemberian ransum pakan dengan benar.

Protein merupakan salah satu komponen pakan yang paling mahal, untuk itu perlu mengurangi proporsi protein pada pakan, sehingga dapat menekan biaya produksi udang namun tidak mengurangi laju pertumbuhan udang yang dibudidayakan. Efisiensi penggunaan pakan merupakan salah satu cara untuk mengurangi biaya produksi sehingga marjin pendapatan yang diperoleh dari penjualan akan semakin tinggi.

Berbagai upaya telah dilakukan untuk menekan biaya produksi pada budidaya udang vaname baik skala laboratorium maupun skala lapangan di antaranya adalah penelitian yang dilakukan oleh Mangampa et al. (2009) tentang penggunaan umur tokolan yang berbeda terhadap pertumbuhan sintasan dan produksi udang vaname di tambak. Informasi diperoleh bahwa tokolan umur 15 hari memberikan hasil terbaik terhadap pertumbuhan, rasio konversi pakan, dan produksi udang di tambak dengan lama pemeliharaan 80 hari. Tahe (2008) pada penelitian pengaruh starvasi ransum pakan terhadap pertumbuhan, sintasan, dan produksi udang vaname dalam wadah terkontrol memperoleh penghematan pakan antara 16,04\%-21,97\% pada perlakuan pengurangan ransum pakan secara periodik hingga $75 \%$ bobot biomassa/minggu. Namun upaya untuk mencari teknologi budidaya yang efektif dan efisien masih perlu dikaji terus agar produk yang dihasilkan dapat bersaing di pasaran ekspor, dengan tidak mengabaikan pertumbuhan dan sintasan udang yang diperoleh. Satu di antara pengelolaan pakan yang telah dikaji adalah kombinasi dua jenis pakan yang memiliki kadar protein yang berbeda. Diharapkan dari hasil penelitian ini diperoleh informasi tentang kombinasi pakan yang optimum terhadap pertumbuhan, sintasan, rasio konversi pakan, dan produksi udang vaname yang dipelihara di bak terkontrol. 


\section{BAHAN DAN METODE}

Penelitian dilaksanakan di Instalasi Perbenihan Barru, Balai Riset Perikanan Budidaya Air Payau, Maros - Sulawesi Selatan. Wadah yang digunakan adalah bak fiber glass ukuran $1 \mathrm{~m} \times 1 \mathrm{~m} \times 0,7 \mathrm{~m}$ sebanyak 9 buah. Penelitian didesain menggunakan Rancangan Acak Lengkap (RAL) dengan tiga perlakuan dan masing-masing 3 ulangan. Perlakuan yang diujikan dalam penelitian ini adalah: (A) pakan PV 100\%, (B) pakan PV 75\% + pakan EB 25\%, dan (C) pakan PV 50\% + EB 50\%. Setiap bak diisi air laut salinitas 32 ppt sebanyak $500 \mathrm{~L}$, dan setiap bak dilengkapi dengan satu batu aerasi. Hewan uji yang digunakan adalah tokolan udang vaname dengan bobot rata-rata $0,45 \pm 0,17 \mathrm{~g} /$ ekor yang ditebar dengan kepadatan 100 ekor/ bak. Selama pemeliharan 85 hari, hewan uji diberi pakan komersial dosis $50-5 \%$ dari biomassa/hari, yang merujuk pada rumus Green et al. (1997) yaitu:

$$
\log Y=-0,899-0,561 \log X
$$

di mana:

$Y=$ Dosis pakan (\% biomassa)

$\mathrm{X}=$ Bobot rata-rata udang $(\mathrm{g})$

Pakan yang diberikan disesuaikan dengan ukuran udang. Uji proksimat pakan yang digunakan disajikan pada Tabel 1 .

Pengukuran bobot hewan uji dilakukan setiap 10 hari dengan menggunakan timbangan elektrik ketelitian 0,01 g. Peubah yang diamati adalah pertumbuhan bobot udang menurut Zonneveld et al. (1991), sintasan udang menurut Effendi (1979), laju pertumbuhan spesifik udang menurut Zonneveld et al. (1991), efisiensi pakan, dan rasio konversi pakan (RKP) (Watanabe, 1988).
Sebagai data pendukung dilakukan analisis kualitas air seperti: suhu, oksigen terlarut, salinitas, $\mathrm{pH}$, fosfat, dan bahan organik total (BOT), amoniak dan nitrit yang diamati setiap 10 hari. Pertumbuhan bobot, sintasan, laju pertumbuhan spesifik, dan rasio konversi pakan dianalisis ragam pada tingkat kepercayaan 95\% yangdilanjutkan dengan uji Beda Nyata Terkecil untuk mengetahui beda nyata antar perlakuan (Steel \& Torrie, 1991).

\section{HASIL DAN BAHASAN}

\section{Pertumbuhan}

Hasil pengamatan terhadap rata-rata bobot akhir udang selama 85 hari pemeliharaan bervariasi dari waktu ke waktu seiring dengan meningkatnya waktu pemeliharaan untuk semua perlakuan seperti terlihat pada Gambar 1 , sedangkan rata-rata bobot akhir udang disajikan pada Tabel 2. Berdasarkan Tabel 2, tampak bahwa pertambahan bobot rata-rata udang tertinggi diperoleh pada perlakuan B (PV 75\% + EB 25\%) sebesar 6,31 $\pm 0,27 \mathrm{~g}$ kemudian disusul perlakuan A (PV 100\%) dan C (PV 50\% + EB 50\%) masing-masing sebesar $5,83 \pm 0,81 \mathrm{~g}$ dan $5,56 \pm 3,41 \mathrm{~g}$. Hasil analisis ragam menunjukkan bahwa pengaruh kombinasi pakan yang berbeda memberikan pengaruh yang berbeda nyata antar perlakuan $(P<0,05)$ terhadap pertambahan bobot rata-rata udang vaname yang dipelihara dalam wadah terkontrol. Menurut Suprapto (2005), agar pertumbuhan udang vaname yang dibudidayakan di tambak dapat tumbuh dengan baik, maka pakan yang diberikan harus memenuhi kualitas dan cukup jumlahnya. Selanjutnya dikatakan bahwa pemberian pakan dalam jumlah yang tepat akan memberikan pertumbuhan yang optimum dan limbah yang terkendali.

Tabel 1. Komposisi proksimat (\%) pakan yang digunakan selama penelitian Table 1. Proximate composition of the feeds used in the experiment

\begin{tabular}{lcccc}
\hline \multirow{2}{*}{$\begin{array}{c}\text { Kombinasi pakan } \\
\text { Feed combination }\end{array}$} & \multicolumn{4}{c}{$\begin{array}{c}\text { Komposisi proksimat } \\
\text { Proximate composition (\%) }\end{array}$} \\
\cline { 2 - 5 } & $\begin{array}{c}\text { Lemak } \\
\text { Lipid }\end{array}$ & Protein & $\begin{array}{c}\text { Serat kasar } \\
\text { Crude fibre }\end{array}$ & $\begin{array}{c}\text { Abu } \\
\text { Ash }\end{array}$ \\
\hline A (PV 100\%) & 6.00 & 33.00 & 3.50 & 13.00 \\
B (PV 75\% + EB 25\%) & 5.34 & 30.08 & 5.75 & 9.86 \\
C (PV 50\%+ EB 50\%) & 6.53 & 27.43 & 4.45 & 11.00 \\
\hline
\end{tabular}




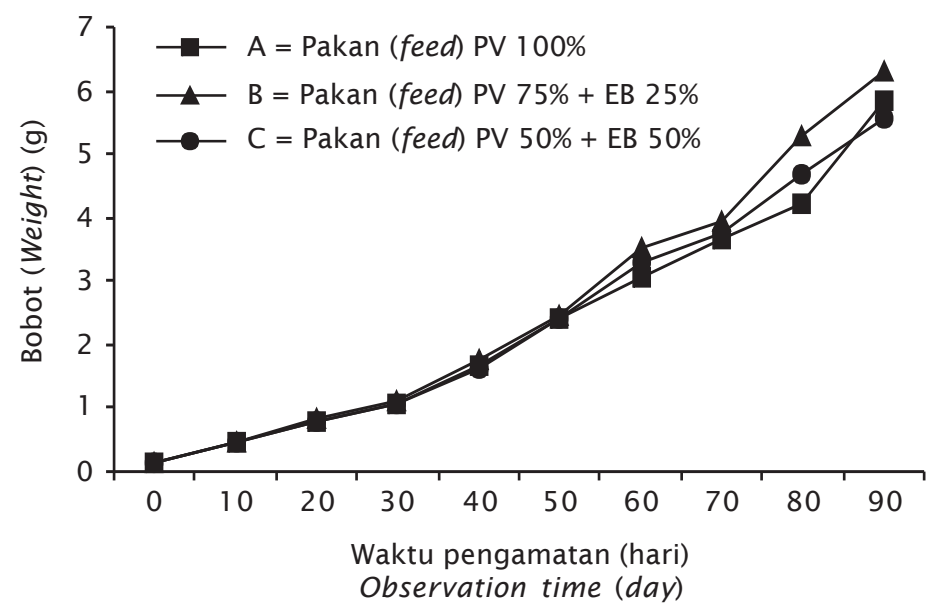

Gambar 1. Pertumbuhan bobot rata-rata udang vaname selama penelitian

Figure 1. Average weight of L. vannamei during the experiment

Tabel 2. Pertambahan biomassa, laju pertumbuhan spesifik, sintasan, rasio konversi pakan, dan produksi udang vaname pada masing-masing perlakuan selama 85 hari pemeliharaan dengan kombinasi pakan berbeda

Table 2. Biomass weight gain, specific growth rate, survival rate, feed conversion ratio and production of L. vannamei for each treatment during 85 days of rearing period

\begin{tabular}{|c|c|c|c|}
\hline \multirow{2}{*}{$\begin{array}{l}\text { Peubah } \\
\text { Variable }\end{array}$} & \multicolumn{3}{|c|}{ Perlakuan (Treat ment) } \\
\hline & $\begin{array}{c}\text { Pakan (Feed) A } \\
\text { (PV 100\%) }\end{array}$ & $\begin{array}{c}\text { Pakan (Feed ) B } \\
(\text { PV 75\% + EB 25\%) }\end{array}$ & $\begin{array}{l}\text { Pakan (Feed) C } \\
\text { (PV 50\% + EB 50\%) }\end{array}$ \\
\hline $\begin{array}{l}\text { Kepadatan (ekor/bak) } \\
\text { Stocking density (ind./tank) }\end{array}$ & 100 & 100 & 100 \\
\hline $\begin{array}{l}\text { Lama pe me liharaan (hari) } \\
\text { Rearing period (days) }\end{array}$ & 85 & 85 & 85 \\
\hline $\begin{array}{l}\text { Bobot awal }(\mathrm{g}) \\
\text { Initial weight }(\mathrm{g})\end{array}$ & $0.45 \pm 0.17$ & $0.45 \pm 0.41$ & $0.45 \pm 0.17$ \\
\hline $\begin{array}{l}\text { Bobot akhir }(\mathrm{g}) \\
\text { Final weight }(g)\end{array}$ & $5.83 \pm 0.81^{\mathrm{a}}$ & $6.31 \pm 0.27^{b}$ & $5.56 \pm 3.41^{c}$ \\
\hline $\begin{array}{l}\text { Pertambahan biomassa }(\mathrm{g}) \\
\text { Biomass weight gain }(\mathrm{g})\end{array}$ & $512.21 \pm 18.66^{a}$ & $518.28 \pm 11.47^{a}$ & $454.34 \pm 45.44^{b}$ \\
\hline $\begin{array}{l}\text { Laju pertumbuhan spesifik (\%) } \\
\text { Specific growth rate (\%) }\end{array}$ & $3.01 \pm 0.10^{\mathrm{a}}$ & $3.10 \pm 0.06^{a}$ & $2.15 \pm 0.31^{\mathrm{a}}$ \\
\hline $\begin{array}{l}\text { Rasio konversi pakan } \\
\text { Feed conversion ratio }\end{array}$ & $1.86 \pm 0.06^{\mathrm{a}}$ & $1.56 \pm 0.10^{\mathrm{a}}$ & $2.04 \pm 0.15^{b}$ \\
\hline $\begin{array}{l}\text { Sintasan (\%) } \\
\text { Survival rate (\%) }\end{array}$ & $93.33 \pm 9.07^{a}$ & $86.00 \pm 1.00^{\mathrm{ab}}$ & $81.66 \pm 1.53^{b}$ \\
\hline $\begin{array}{l}\text { Produksi (g) } \\
\text { Production (g) }\end{array}$ & $512.66 \pm 18.66^{a}$ & $518.73 \pm 11.47^{a}$ & $454.74 \pm 45.44^{b}$ \\
\hline
\end{tabular}


Soemardjati \& Suriawan (2006) mengatakan bahwa kegiatan paling penting dalam budidaya udang vaname adalah pemberian pakan. Pakan yang diberikan harus memenuhi kebutuhan nutrisi bagi pertumbuhan udang yang dibudidayakan serta harus disesuaikan dengan kebiasaan makan dan tingkah laku udang itu sendiri. Nutrisi pakan terdiri atas protein, lemak, dan karbohidrat. Udang vaname memerlukan formulasi pakan dengan kandungan protein antara 28\%-30\%. Apabila dilihat dari hasil proksimat analisis pakan yang dilakukan sebelum pemeliharaan (Tabel 1), maka kadar protein 30\% secara teknis sudah sesuai dengan kebutuhan nutrisi udang. Jika dilihat dari perbedaan harga pakan, perlakuan B dapat menghemat biaya pakan bila dibandingkan dengan pakan pada perlakuan A, sedangkan perlakuan $\mathrm{C}$ memberikan respon pertumbuhan udang yang lambat. Hal ini diduga disebabkan nilai nutrisi yang dikandung pada pakan ini terlalu rendah khususnya kadar protein hanya $27 \%$. Kadar protein dalam pakan merupakan zat makanan yang sangat dibutuhkan untuk pemeliharaan tubuh, pembentukan jaringan tubuh yang rusak serta penambahan protein tubuh dalam proses pertumbuhan. Hasil penelitian ini tidak jauh berbeda dengan penelitian Tahe \& Suwoyo (2009) yang memperoleh pertumbuhan udang vaname pada penelitian jenis pakan yang berbeda yaitu perlakuan pakan EB sebesar 6,4 g/ekor, perlakuan pakan PV 6,3 g/ekor dan perlakuan pakan IR sebesar 5,98 g/ekor menggunakan wadah fiber glass dengan kepadatan 100 ekor/ bak. Namun jika dibandingkan dengan hasil penelitian Green at al. (1997) yang menggunakan dosis pakan $50 \%$ dari kurva pertumbuhan dengan perlakuan persentase protein pakan (20\% dan $30 \%$ ) memperoleh bobot rata-rata udang vaname sedikit lebih rendah yaitu 6,7-6,1 g/ekor, produksi bersih 412-490 kg, sintasan 21\%-31\% dan RKP 0,9-1,0 selama 87 hari pemeliharaan.

Tahe \& Suwoyo (2009) mendapatkan pertumbuhan udang vaname pada frekuensi pemberian pakan $4 \mathrm{kali} /$ hari dengan bobot ratarata akhir udang 7,55 g sedangkan pada frekuensi $3 \mathrm{kali} /$ hari dan frekuensi $2 \mathrm{kali} /$ hari masing-masing diperoleh bobot akhir rata-rata 6,94 dan 6,13 g. Perbedaan bobot akhir ratarata udang yang diperoleh bila dibandingkan dengan hasil penelitian ini disebabkan perbedaan padat penebaran hewan uji yang dicobakan.
Laju pertumbuhan spesifik udang vaname yang diperoleh pada akhir penelitian (Tabel 2), berada pada kisaran 2,15\%-3,10\%/hari. Hasil analisis ragam menunjukkan bahwa laju pertumbuhan spesifik berbeda tidak nyata $(P>0,05)$ antar perlakuan selama 85 hari pemeliharaan. Laju pertumbuhan spesifik udang vaname yang diperoleh pada penelitian ini lebih rendah bila dibandingkan dengan hasil yang diperoleh dari penelitian Tahe (2009), yang memperoleh laju pertumbuhan spesifik udang vaname yang dipelihara pada perlakuan jenis pakan yang berbeda yaitu pakan EB 5,64\% sedangkan perlakuan PV dan IR masing-masing 5,62\% dan 5,56\%. Hendrajat \& Mangampa (2007) mendapatkan laju pertumbuhan harian udang vaname pada pemeliharaan tradisional plus pada kepadatan 4, 6, dan 8 ekor masing-masing sebesar 9,23\%; 9,19\% dan 9,05\%/hari. Selanjutnya Rachmansyah et al. (2006) memperoleh laju pertumbuhan harian udang vaname berkisar 9,48\%-9,52\%/hari selama 100 hari pemeliharaan. Bila dibandingkan lagi dengan hasil yang diperoleh Arifin et al. (2007) yang memperoleh laju pertumbuhan harian udang vaname pola sederhana selama 60 hari pemeliharaan sebesar 14\%/hari, maka laju pertumbuhan udang vaname dari penelitian ini juga tergolong lebih rendah. Perbedaan laju pertumbuhan spesifik udang vaname antara hasil penelitian yang diperoleh dengan beberapa hasil penelitian sebelumnya disebabkan adanya perbedaan bobot akhir yang diperoleh yang sangat terkait dengan perbedaan wadah penelitian (tambak) dan respon pakan yang digunakan.

\section{Sintasan Udang}

Sintasan udang yang diperoleh selama 85 hari pemeliharaan dalam bak terkontrol disajikan pada Tabel 2. Berdasarkan tabel tersebut tampak bahwa sintasan udang yang tertinggi diperoleh pada perlakuan $\mathrm{A}$ sebesar 93,33\%, menyusul perlakuan B dan C adalah masing-masing $86,0 \%$ dan $81,66 \%$. Uji analisis ragam menunjukkan bahwa perlakuan kombinasi pakan memberikan pengaruh nyata $(P<0,05)$ terhadap sintasan undang vaname yang dipelihara. Hasil uji lanjut diperoleh informasi bahwa perlakuan A memberikan respon yang sama dengan perlakuan $B$ tetapi berbeda nyata dengan perlakuan C, sedangkan perlakuan B berbeda tidak nyata dengan perlakuan C. Rendahnya sintasan 
yang diperoleh pada perlakuan $\mathrm{C}$ diduga disebabkan oleh rendahnya kadar protein pakan yang diberikan sehingga kebutuhan nutrien dalam pertumbuhannya tidak tercukupi. Selain itu, diduga disebabkan oleh kanibalisme udang vaname yang dipelihara muncul akibat rendahnya kualitas pakan yang diberikan. Bardach et al. (1972) mengemukakan bahwa salah satu faktor yang menunjang laju pertumbuhan dan sintasan udang budidaya di tambak khususnya semiintensif adalah ketersediaan pakan yang sesuai dan mencukupi kebutuhan nutrisinya. Nilai sintasan udang vaname yang diperoleh pada penelitian ini sedikit lebih rendah jika dibandingkan dengan hasil penelitian sebelumnya. Tahe (2008) mendapatkan sintasan udang 93,33\% pada perlakuan frekuensi 4 kali/hari, menyusul frekuensi 2 kali/hari, dan frekuensi 3 kali/hari yaitu masing-masing 93,33\% dan 91,33\%. Wyban \& Sweeny (1991) mengemukakan bahwa pemberian pakan yang tepat baik dari segi kualitas maupun dari segi jumlahnya sangat mempengaruhi pertumbuhan dan mencegah kanibalisme udang yang pada akhirnya meningkatkan sintasan udang.

Hasil uji statistik menunjukkan bahwa pengaruh perlakuan terhadap produksi udang diperoleh perbedaan yang nyata $(P<0,05)$. Uji lanjut menunjukkan bahwa produksi perlakuan A berbeda tidak nyata dengan produksi yang diperoleh pada perlakuan B akan tetapi berbeda nyata dengan produksi pada perlakuan C. Produksi yang diperoleh pada penelitian ini lebih tinggi jika dibandingkan dengan hasil yang diperoleh Tahe (2008) pada penelitian perbedaan substrat dasar yaitu substrat tanah, substrat pasir, dan tanpa substrat yaitu masing-masing 290,38 g; 306,62 g; dan 308,28 g dengan lama pemeliharaan 60 hari. Tingginya produksi yang diperoleh pada penelitian ini disebabkan oleh tingginya padat tebar yang diaplikasikan pada penelitian ini. Suwoyo et al. (2005) mendapatkan produksi udang vaname secara tunggal ( 100 ekor $\left./ 0,5 \mathrm{~m}^{3}\right)$ dan kombinasi 80 ekor udang vaname +20 ekor udang windu masing-masing sebesar 473 dan $431 \mathrm{~g} / 0,5 \mathrm{~m}^{3}$. Menurut Stickney (1979), produksi dipengaruhi oleh laju pertumbuhan, makanan, padat penebaran, dan merupakan hasil perkalian antara sintasan udang dengan bobot akhir rata-rata.

\section{Konversi Pakan}

Nilai rasio konversi pakan yang diperoleh pada penelitian ini sedikit lebih tinggi jika dibandingkan dengan hasil kajian budidaya udang vaname sebelumnya. Anonim (2003) mendapatkan RKP 1,3 untuk budidaya udang vaname dengan kepadatan 90 ekor $/ \mathrm{m}^{2}$, sintasan 70\%-90\% dan bobot udang rata-rata saat panen $20 \mathrm{~g} /$ ekor dengan lama pemeliharaan 110 hari. Trenggono (2003) mendapatkan RKP udang vaname sebesar 1,4 yang dipelihara di tambak dengan kepadatan 90 ekor $/ \mathrm{m}^{3}$ dengan lama pemeliharaan 110 hari. Haliman \& Adijaya (2005) melaporkan bahwa udang vaname di Situbondo-Jawa Timur dengan padat tebar 150 ekor $/ \mathrm{m}^{2}$ diperoleh sintasan $85 \%$, bobot akhir 14,28 g/ekor dan menghasilkan udang sebanyak $5.465 \mathrm{~kg} /$ $3.000 \mathrm{~m}^{2}$ dengan RKP 1,5. Selanjutnya Tahe et al. (2008) mendapatkan rasio konversi pakan (FCR) relatif lebih rendah yaitu 1,27 pada penelitian pengurangan ransum pakan 75\%BW/hari/minggu di dalam akuarium kaca dengan kepadatan 50 ekor/akuarium $(75 \mathrm{~cm} \times$ $50 \mathrm{~cm} \times 60 \mathrm{~cm}$ ), sintasan berkisar 73,89\%$83,11 \%$ dengan lama pemeliharaan 75 hari. Untuk meningkatkan efisiensi penggunaan pakan dalam budidaya udang vaname salah satu hal yang perlu diperhatikan adalah kualitas pakan. Sutanto (2005) mengemukakan bahwa kadar protein 30\% cukup baik digunakan pada budidaya udang vaname, karena dapat mengurangi pencemaran/lebih ramah lingkungan, pertumbuhan udang yang baik dan pengelolaan air yang mudah, RKP lebih rendah sehingga biaya pakan menjadi lebih murah. Huet (1971) menyatakan bahwa, RKP dipengaruhi oleh sintasan, kepadatan, bobot individu, perbedaan persentase pakan harian, waktu, dan lokasi pemeliharaan. Semakin rendah nilai RKP semakin baik karena sedikit jumlah makanan yang dimanfaatkan untuk meningkatkan bobot udang.

Hasil analisis ragam menunjukkan bahwa perlakuan kombinasi pakan yang berbeda pada pemeliharaan udang vaname menunjukkan hasil yang berbeda nyata $(P<0,05)$ terhadap RKP yang diperoleh. Uji lanjut memberikan informasi bahwa nilai rasio konversi pakan pada perlakuan A memberikan nilai RKP yang berbeda tidak nyata dengan perlakuan B dan berbeda secara nyata dengan nilai rasio konversi pakan pada perlakuan C. 


\section{Kualitas Air}

Kualitas air mempunyai peranan penting sebagai pendukung kehidupan dan pertumbuhan udang vaname. Hasil pengamatan terhadap beberapa peubah kualitas air yang meliputi: suhu, salinitas, $\mathrm{pH}$, oksigen terlarut, amoniak, nitrit, nitrat, fosfat, dan BOT pada semua perlakuan selama penelitian disajikan pada Tabel 3. Rendahnya kualitas air pada media pemeliharaan dapat mengakibatkan rendahnya tingkat pertumbuhan dan sintasan udang. Kualitas air selama penelitian masih berada pada kisaran yang layak bagi pertumbuhan dan sintasan udang vaname kecuali kadar amoniak yang sedikit agak tinggi, namun tampaknya masih dapat ditolerir hewan uji selama pemeliharaan. Kualitas air yang layak untuk budidaya udang vaname adalah salinitas optimum 10-25 ppt (toleransi $50 \mathrm{ppt}$ ), suhu air $28-31^{\circ} \mathrm{C}$ (toleransi $16-36^{\circ} \mathrm{C}$ ), oksigen terlarut $>4 \mathrm{mg} / \mathrm{L}$ (toleransi minimum $0,8 \mathrm{mg} / \mathrm{L}$ ), $\mathrm{pH}$ 7,5-8,2, alkalinitas $120-150 \mathrm{mg} / \mathrm{L}$, amoniak < $0,1 \mathrm{mg} / \mathrm{L}$, fosfat $0,5-1 \mathrm{mg} / \mathrm{L}$, dan $\mathrm{H}_{2} \mathrm{~S}<0,003$ $\mathrm{mg} / \mathrm{L}$ (Anonim, 2003).

Menurut Suprapto (2005), suhu dan kadar oksigen terlarut optimum untuk budidaya udang vaname berkisar $27-32^{\circ} \mathrm{C}$ dan $>3$ $\mathrm{mg} / \mathrm{L}$ dan bisa tahan sampai $10^{\circ} \mathrm{C}$. Suhu air yang diperoleh selama penelitian rata-rata $28^{\circ} \mathrm{C}$ dan oksigen terlarut rata-rata $4,42 \mathrm{mg} / \mathrm{L}$. Suhu air mempunyai peranan penting dalam mengatur aktivitas udang seperti halnya hewan air lainnya. Haliman \& Adijaya (2005) menambahkan bahwa suhu optimum pertumbuhan udang vaname antara $26^{\circ} \mathrm{C}-32^{\circ} \mathrm{C}$. Beberapa peubah kualitas air lainnya diduga berpengaruh pada laju pertumbuhan udang yang dibudidayakan. Suprapto (2005) melaporkan bahwa salinitas optimum untuk pertumbuhan udang vaname adalah 15-25 ppt. Sedangkan Bray et al. (1994) menerangkan bahwa pertumbuhan udang vaname pada salinitas 5-15 ppt lebih tinggi secara nyata dibanding pada salinitas $49 \mathrm{ppt}$. Menurut McGraw \& Scarpa (2002), udang vaname dapat hidup pada kisaran salinitas yang lebar dari 0,5-45 ppt. Wyban \& Sweeny (1991) mengemukakan bahwa kisaran $\mathrm{pH}$ air yang cocok untuk budidaya udang vaname secara intesif sebesar 7,4-8,9 dengan nilai optimum 8,0 .

Amoniak merupakan salah satu hasil sampingan dari proses perombakan bahan organik di dalam air yang dapat bersifat racun. Toksisitas amoniak meningkat dengan

Tabel 3. Rata-rata dan standar deviasi peubah kualitas air yang diukur selama penelitian

Table 3. Average and water quality deviasion during the experiment

\begin{tabular}{|c|c|c|c|}
\hline \multirow{2}{*}{$\begin{array}{l}\text { Peubah } \\
\text { Variable }\end{array}$} & \multicolumn{3}{|c|}{ Perlakuan (Treatment) } \\
\hline & $\begin{array}{c}\text { Pakan (Feed) A } \\
\text { (PV 100\%) }\end{array}$ & $\begin{array}{c}\text { Pakan (Feed) B } \\
\text { (PV 75\% + EB 25\%) }\end{array}$ & $\begin{array}{l}\text { Pakan (Feed) C } \\
\text { (PV 50\% + EB 50\%) }\end{array}$ \\
\hline $\begin{array}{l}\text { Suhu }\left({ }^{\circ} \mathrm{C}\right) \\
\text { Temperature }\left({ }^{\circ} \mathrm{C}\right)\end{array}$ & $28.40 \pm 0.51$ & $28.54 \pm 0.46$ & $28.40 \pm 0.35$ \\
\hline $\begin{array}{l}\mathrm{pH} \\
\mathrm{pH}\end{array}$ & $8.65 \pm 0.46$ & $8.60 \pm 0.64$ & $8.50 \pm 0.54$ \\
\hline $\begin{array}{l}\text { Salinitas (ppt) } \\
\text { Salinity (ppt) }\end{array}$ & $32.39 \pm 1.25$ & $32.65 \pm 1.28$ & $32.50 \pm 1.57$ \\
\hline Oksigen te rlarut (mg/L) & & & \\
\hline $\begin{array}{l}\text { Dissolved oxygen }(\mathrm{mg} / \mathrm{L}) \\
\text { Amoniak }(\mathrm{mg} / \mathrm{L})\end{array}$ & $4.54 \pm 0.57$ & $4.54 \pm 0.35$ & $4.45 \pm 0.65$ \\
\hline $\begin{array}{l}\text { Ammonium (mg/L) } \\
\text { Nitrit (mg/L) }\end{array}$ & $0.622 \pm 1.21$ & $0.738 \pm 0.97$ & $0.817 \pm 1.0$ \\
\hline $\begin{array}{l}\text { Nitrite }(\mathrm{mg} / \mathrm{L}) \\
\mathrm{BOT}(\mathrm{mg} / \mathrm{L})\end{array}$ & $0.135 \pm 0.24$ & $0.267 \pm 0.18$ & $0.246 \pm 0.23$ \\
\hline Total Organic Matter $(\mathrm{mg} / \mathrm{L})$ & $46.57 \pm 3.56$ & $47.75 \pm 4.20$ & $49.36 \pm 5.67$ \\
\hline
\end{tabular}


menurunnya kadar oksigen terlarut. Konsentrasi amoniak dalam penelitian ini mencapai antara 0,622-0,817 mg/L. Tingginya kosentrasi amoniak yang diperoleh pada penelitian ini diduga disebabkan oleh akumulasi sisa pakan dan kotoran udang yang menyebabkan amoniak meningkat. Toksisitas peubah kualitas air tidak bekerja secara sendiri-sendiri artinya bahwa sekalipun kadar amoniak melebihi ambang batas kehidupan akan tetapi peubah lainnya masih pada tingkat optimal maka, tidak akan mematikan udang. Konsentrasi $\mathrm{NH}_{3}$ yang relatif aman untuk udang Penaeus sp adalah di bawah $0,1 \mathrm{mg} / \mathrm{L}$ (Liu, 1989). Lin \& Chen (2001) melaporkan bahwa nilai LC $_{50}$ amoniak untuk yuwana udang vaname pada perendaman $24,48,72$, dan 96 jam dan salinitas 35 ppt yakni 2,78; 2,18; 1,82; dan 1,60 mg/L. Selanjutnya Tsai (1989) dalam Hadie et al. (1995) menambahkan bahwa batas aman amoniak pada udang adalah $0,1 \mathrm{mg} / \mathrm{L}$. Kadar amoniak mulai berpengaruh terhadap pertumbuhan $50 \%$ adalah pada kadar 0,45 $\mathrm{mg} / \mathrm{L}$, sedangkan pada kadar 1,29 mg/L menyebabkan kematian. Adiwijaya et al. (2003) berpendapat bahwa kisaran optimum nitrit untuk budidaya vaname yakni 0,01-0,05 $\mathrm{mg} / \mathrm{L}$ sedangkan kisaran optimal bahan organik total pada budidaya udang vaname $<55$ mg/L. Menurut Clifford (1994), konsentrasi nitrat yang optimum untuk udang vaname berkisar 0,4-0,8 mg/L.

\section{KESIMPULAN DAN SARAN}

Hasil penelitian menunjukkan bahwa kombinasi pakan berpengaruh nyata terhadap pertumbuhan, sintasan, rasio konversi pakan, dan produksi udang vaname selama pemeliharaan. Pertumbuhan bobot akhir rata-rata, sintasan, dan produksi udang vaname terbaik masing-masing 6,31 g/ekor; 86,0\%; dan 518,73 $\mathrm{g}$ diperoleh pada perlakuan $\mathrm{B}$ (kombinasi pakan PV $75 \%$ + pakan EB 25\%) dibanding dengan perlakuan lainnya. Untuk efisiensi biaya produksi, disarankan mengkombinasikan pakan PV dan EB pada pemeliharaan udang vaname skala lapang.

\section{UCAPAN TERIMA KASIH}

Penelitian ini dapat terlaksana berkat bantuan Sdr. Abidin, Rijal, dan Burhanuddin selaku teknisi di lapangan dan Sdri. Sutrisyani, Rahmatia, dan Sarijanna atas bantuannya dalam menganalisis kualitas air di laboratorium, untuk itu diucapkan terima kasih, semoga penelitian ini dapat bermanfaat.

\section{DAFTAR ACUAN}

Adiwijaya, D., Sapto, P.R., Sutikno, E., Sugeng, \& Subiyanto. 2003. Budidaya udang vaname (Litopenaeus vannamei) sistem tertutup yang ramah lingkungan. Departemen Kelautan dan Perikanan, Balai Besar Pengembangan Budidaya Air Payau, Jepara, $29 \mathrm{hlm}$.

Anonim. 2003. Litopenaeus vannamei sebagai alternatif budidaya udang saat ini. PT. Central Protein Prima (Charoen Pokphand Group) Surabaya, $18 \mathrm{hlm}$.

Arifin, Z., Andrat, K., \& Subiyanto. 2007. Teknik produksi udang vaname (Litopenaeus vannamei) secara sederhana. Departemen Kelautan dan Perikanan. Balai Besar Pengembangan Budidaya Air Payau Jepara, $9 \mathrm{hlm}$.

Bardach, J.E., Ryther, J.H., \& Mclarney, W.O. 1972. Aquaculture: The farming and husbandry of freshwater and marine organisms. WileyInterscience Pub., New York, 868 pp.

Bray, W.A., Lawrence, A.L., \& Leung Trujillo, J.R. 1994. The effect of salinity on growth and survival of Penaeus vannamei, with observations on in the interaction of IHHN virus and salinity. Aquaculture, 122: 133-146.

Clifford, H.C. 1994. Management of ponds stocked with Blue Shrimp Litopenaeus stylirostris. In Print, Proceedings of the $1 \mathrm{st}$ Latin American Congress on Shrimp Culture, Panama City, Panama, p. 101-109.

Effendie, M.I. 1979. Metode Biologi Perikanan. Cetakan Pertama. Penerbit Yayasan Dwi Sri Bogor, $112 \mathrm{hlm}$.

Green, B.W., Teichert-Coddington, D.R., Boyd, C.E., Harvin, J.L., Corrales, H., Zelaya, R., Martinez, D., \& Ramirez, E. 1997a. The effect of pond management Strategies on Nutrien Budgets: Honduras. In Egna, H., Gootze, B., Burke, D., Mc.Namara and D.clair (eds). Fourteenth Annual Technical Report 1996. Ponds Dynamics/Aquaculture CRSP, Office of International Research and Development, Oregon State University, Corvallis, Oregon, p. 77-82.

Hadie, W., Rejeki, S., \& Hadie, L.E. 1995. Pengaruh pemotongan tangkai mata (ablasi) terhadap pertumbuhan juvenil udang galah (Macrobarnchium rosembergii). J. Pen. Perik. Indonesia, 1(1): 37-44. 
Haliman, R.W. \& Adijaya, S.D. 2005. Udang vannamei, Pembudidayaan dan Prospek Pasar Udang Putih yang Tahan Penyakit. Penebar Swadaya, Jakarta, $75 \mathrm{hlm}$.

Hendrajat, E.A. \& Mangampa, M. 2007. Pertumbuhan dan sintasan udang vaname (Litopenaeus vannamei) pola tradisional plus dengan kepadatan berbeda. J. Ris. Akuakultur, 2(2): 149-155.

Holthuis, L.B., Rjksmuseum van, H., \& Leiten. 1980. FAO Species Cataloque Shrimp and Prawn of the world. Vol 1. An Annatated Cataloque of species of interest Fisheries. FAO of the United Nations. Rome, 272 pp.

Huet, M. 1971. Textbook of Fish Culture, Cyre and Sportis Woode Ltd, London, 436 pp.

Lin, Y.C. \& Chen, J.C. 2001 . Acute toxicity of ammonia on Litopenaeus vannamei boone juveniles at different salinity levels. Journal of Experimental Marine Biology and Ecology, 259(1): 109-119.

Liu, C.I. 1989. Shrimp disease, prevention and treatment. In: Akiyama D.M, eds. Proceeding of the Southeast Asia Shrimp Farm Management workshop. USA:Soybeans, America Soybean Association, Singapura, p. 64-74.

Mangampa, M. 2007. Pengaruh penggunaan benih tokolan pada budidaya udang vanamei semi intensif. Balai Riset Perikanan Budidaya Air Payau, Maros.

Mangampa, M., Tahe, S., \& Suwoyo, H.S. 2009. Riset budidaya udang vaname tradisional plus menggunakan benih tokolan dengan ukuran yang berbeda. Konferensi Akuakultur Indonesia. MAI, Yogyakarta, $11 \mathrm{hlm}$.

McGraw, W.J. \& Scarpa, J. 2002. Determining ion concentration for Litopenaeus vannamei culture in freshwater. Global Aquaculture, Advocate, 5(3): 36-37.

Padda., H. \& Mangampa, M. 1993. Analisis ekonomi percobaan pergantian air dan lama aerasi dalam budidaya udang windu secara intensif di tambak Marana, Kabupaten Maros, Sulawesi Selatan. Prosiding Seminar Hasil Penelitian Perikanan Budidaya Pantai Maros, 16-19 Juli 1993,11: 161-168.

Palinggi, N.N. \& Atmomarsono, M. 1988. Pengaruh beberapa jenih bahan baku pakan terhadap pertumbuhan udang windu (Penaeus monodon Fabr.) J. Penel. Budidaya Pantai, 1(4): 21-28.

Poernomo, A. 2002. Perkembangan udang putih vannamei (Penaeus vannamei) di Jawa
Timur. Disampaikan dalam Temu Bisnis Udang. Makassar, 19 Oktober 2002, 26 hlm.

Rachmansyah, Suwoyo, H.S., Undu, M.C., \& Makmur. 2006. Pendugaan Nutrient Budget tambak intensif udang Litopenaeus vannamei. J. Ris. Akuakultur, 1(2): 181-202.

Soemardjati, W. \& Suriawan, A. 2006. Petunjuk teknis budidaya udang vaname (Litopenaeus vannamei) di Tambak. Departemen Kelautan dan Perikanan. Direktorat Jenderal Perikanan Budidaya. Balai Budidaya Air Payau Situbondo, 30 hlm.

Steel, R.G.D. \& Torrie, J.H. 1991. Principles and Procedures of Statistics. London: McGrawHill, Book Company, Inc., 87 pp.

Suprapto. 2005. Petunjuk teknis budidaya udang vannamei (Litopenaeus vannamei). CV. Biotirta. Bandar Lampung, 25 hlm.

Sutanto, I. 2005. Kesuksesan budidaya udang vannamei (Litopenaeus vannamei) di Lampung. dalam A. Sudrajat, Azwar, Z.I., Hadi, L.E, Haryanti, Giri, N.A., \& Sumiarsa, G.S. 2005. Buku Perikanan Budidaya Berkelanjutan. Pusat Riset Perikanan Budidaya. Badan Riset Kelautan dan Perikanan, hlm. 67-72.

Stickney, R. 1979. Principle of warm water aquaculture. New York, Chichester. Brisbane. Toronto.

Suwoyo, H.S., Yakob, M.J.R., Lante, S., \& Mangampa, M. 2005. Pengaruh keberadaan udang vaname (Litopenaeus vannamei) pada budidaya udang windu (Penaeus monodon) dalam bak terkontrol. Prosiding Konferensi Nasional IV Pengelolaan Sumberdaya Perairan Umum, Pesisir, PulauPulau Kecil dan Laut Indonesia, Balikpapan 14-17 September 2004.

Tahe, S. 2008. Pengaruh starvasi ransum pakan terhadap pertumbuhan sintasan dan produksi udang vaname (Litopenaeus vannamei) dalam wadah terkontrol. J. Ris. Akuakultur, III(3): 401-412.

Tahe, S. 2009. Pengaruh perbedaan frekuensi pemberian pakan terhadap pertumbuhan sintasan dan produksi udang vanamei (Litopenaeus vanamei) pada bak terkontrol. Prosiding Seminar Nasional Kelautan IV. Universitas Hang Tuah Surabaya, $11 \mathrm{hlm}$.

Tahe, S., Suwoyo, H.S., \& Mansyur, A. 2008. Pengaruh substrat dasar terhadap pertumbuhan, sintasan, dan produksi udang vaname skala laboratorium. Prosiding Seminar Nasional Perikanan 
Indonesia, Sekolah Tinggi Perikanan di Jakarta.

Tahe, S. \& Suwoyo H.S. 2009. Pertumbuhan dan sintasan udang vaname (Litopenaeus vannamei) dengan pemberian pakan yang berbeda. Prosiding Seminar Nasional Perikanan 2009. Sekolah Tinggi Perikanan di Jakarta, hlm. 332-339.

Trenggono, E. 2003. Timbang lagi keputusan anda bertambak vannamei. Trobos. Edisi Mei 2003, 44: 61-63.
Watanabe, T. 1988. Fish nutrition and mariculture. JICA textbook. The General Aquaculture Course. Japan, $233 \mathrm{pp}$.

Wyban, J.A. \& Sweeny, J.N. 1991. Intensive Shrimp Production Technology. The Oceanic Institute Makapuu Point. Honolulu, Hawai USA, 158 pp.

Zonneveld, N.E., Huisman, A., \& Boom, J.H. 1991. Prinsip-prinsip Budidaya Ikan. Pustaka Utama. Gramedia, Jakarta, $318 \mathrm{hlm}$. 